\title{
Chabani Manganyi: Black intellectual and psychologist ${ }^{1}$
}

Chabani Manganyi's work over many years now has caught the attention of discerning readers and critical scholars alike, and so a new book by him is certain to be anticipated with much interest. In his latest book, Apartheid and the making of a Black psychologist, he turns his biographical craft, that he has become renowned for, on himself. Manganyi starts his memoir telling us about his childhood growing up in Mavambe (what is now Limpopo province), and ends it with his years spent in the service of higher education, first as vice chancellor of the University of the North, and then as the director general of education under Mandela's presidency. Impressive as these commitments to the cause of higher education in South Africa are, yet what really distinguishes Chabani Manganyi is the slew of excellent texts that he has produced since his early thirties (starting with the seminal Being-black-in-the-world in 1973; and then 1977a; 1977b; 1981; 1983; 1990; 1991; 1996; 2004a; 2004b; 2010; 2012; 2016), covering, amongst other things, the psychosocial intricacies of black subjectivity (especially within the constraints of apartheid social relations), through to wonderful biographies of Es'kia Mphahlele, Gerard Sekoto, and Dumile Feni.

In keeping with the spirit of Manganyi's memoir I would like to make a few brief introductory and contextual comments from my own autobiographical perspective (for further contextual comments, see Hayes, 2011). In other words, I shall say a few things about the history of Manganyi's work through my association with it. Choosing this autobiographical approach is not because

\section{Grahame Hayes}

University of KwaZulu-Natal Durban

grahame.hayes@gmail.com 
of some narcissistic impulse on my part, but because I think it says something revealing about the importance and influence of Manganyi's work and ideas for my generation of academics and left intellectuals during the time of apartheid. First, a disclosure: Chabani Manganyi is not my exact age peer, but he is not that much older than me. The 11 years difference between us is quite significant when the one person is in their late 20 s and starting out as an academic and the other is in their late 30s, and in the case of Manganyi, by then quite established in his academic work and writing. It was Manganyi's first book, published by Spro-cas/Ravan in 1973, called Being-black-in-the world, a collection of essays on the "black experience", as he framed it back then, that had a huge influence on a young generation of left-leaning, anti-apartheid, mostly white, aspiring academics and intellectuals. I recall using his postscript essay "African time" in my early days as a lecturer as a basis to critique essentialist notions of identity, and to undermine the racism of certain bits of psychological research that claimed to be objective and scientific. This short piece is a wonderful debunking of an article published in 1972 by a certain F J Engelbrecht called "Tyd en neurose by die Bantu" ("The Bantu, time and neuroses").

What struck many us was the style of writing and argument in these essays. They were unlike the stuff we had been required to read and study in our undergraduate and postgraduate courses in psychology, and what's more we had a black South African as an "intellectual and political ally". In those days, and it is still probably true much of the time now, we read very little literature that was South African. What particularly stood out in those early essays, at the time, and again recently when reading Manganyi's memoir, is the generosity of spirit in his critiques of the alienation and indignities black people were constantly being subjected to. I kept on thinking: "Why isn't this guy more angry?" For instance, he writes: "The public marriage between the words 'black' and 'consciousness' has in some instances led to some panic and public consternation in certain sections of the South African public." (Manganyi, 1973: 17; emphases added). Somewhat understated one might say given how the apartheid government reacted to all things to do with black consciousness! This is the opening sentence to the essay "Black consciousness", which presents a nuanced psycho-philosophical / existentialist reading of the black experience, of being-black-in the-world, through the lens of the work of the currently fashionable Frantz Fanon, and the less fashionable Sartre and Merleau-Ponty. The student \#Fallists activists would do well to read this text of Manganyi's as they plot a course of action for de-colonising the curriculum. It is encouraging to note that recently a critical intellectual of the stature of Njabulo Ndebele has recently been re-reading Manganyi's text of 1973. Ndebele (2016:11) has this to say: "Reading this book [Being-black-in-the-world] in 2016 got me to ask another set of questions. What if the student activists of the \#RhodesMustFall Movement had in large numbers encountered this book in their undergraduate syllabus at any South African university they had randomly chosen to attend? What if they had studied this 
book together with the writings of Steve Biko, Frantz Fanon, Walter Rodney, or C L $\mathrm{R}$ James and other related books as part of a 'canon' of curriculum fare ..." What if, indeed, and sadly even these days the so-called progressive faculty at our universities seem not to study Manganyi's works "as part of a canon of curriculum fare".

A lot more could, and should, be said about this important first text of Manganyi's, but let me add just one further observation. The mainstream of the psychology establishment was not reading Manganyi's work, and I and others came upon his work through circuitous political connections, and through the publications brought out by Spro-cas, and later Ravan Press. It is this silence from within Psychology that is in some ways a bit odd, if not downright troubling. A thoroughgoing critique, or even rejection, of his ideas would have meant that his work had at least been read and engaged with. A benign interpretation of this silence might be that his ideas were found to be too unsettling and hence left the reader not sure what to say or think. A more negative view of course would be that the political challenge of his work would undermine the bourgeois complacency of much so-called "scientific" psychology, and especially the uncomfortable truth about South African psychology's complicity with apartheid. I would go so far as to say that the institution of Psychology has never really properly acknowledged Manganyi's profound contributions to the discipline. I know that there has recently been a belated acknowledgement from PsySSA bestowing a fellowship on him in 2012. And in 2008 Catriona Macleod, then Head of Psychology at Rhodes, invited him to give a public lecture, which Manganyi credits as getting him on the road to tell his story that has become the memoir. I can't speak for PsySSA, but Catriona Macleod is no ordinary mainstream psychologist, her credentials are much more radical and feminist. When you read Chabani Manganyi's memoir you will notice that even he wonders about this silence, about this lack of recognition. After all, he finished his PhD in 1970, when many were not getting PhDs in those days; he had started publishing articles in the late 1960s; he was working both as a clinician and a researcher; his first book had just appeared; and yet no academic posts were forthcoming! On his return from the US in the mid-1970s he did take up a post at UNITRA, first as head of psychology, and then as dean, before taking up a position at the African Studies Institute at Wits in 1980. So formally, a very brief period of his intellectual life has been in psychology.

Manganyi should be somewhat relieved that the Psychology establishment didn't take him seriously. It is a case of the Groucho Marx comment that he didn't want to be a member of a club that would have him as member! What would it have meant for South African Psychology to give recognition to Manganyi's work? It would have entailed a revolution in the content and approach of the discipline, or would have meant that they got his work so wrong that it didn't threaten how the discipline conceived its theory and practice. However, for many of my generation, Chabani Manganyi's work 
represented the kind of ideas and thinking that we were looking for in Psychology, but found sorely lacking.

So what was the content of his work that so many of us found fascinating during the decades of the 1970s and 1980s? Much of the content of what could be called his psychological work involves a series of carefully considered social, and political engagements, with the society in which he found himself, and found himself as a black man seen as lesser by an oftentimes brutal and inhumane, not to mention illegitimate, government. He was writing about violence, about alienation, about racism, about the effects of oppression on the minds and bodies of black people. Hardly the standard fare of academic psychology in the 1980s, if it is even so today.

His work, in my view, also has a strong moral dimension to it, and this is particularly evident in his work on political violence (see the edited collection with André du Toit published in 1990), and his appearance as an expert witness in political trials (see chapters 5, $6 \& 7$ of his memoir). Psychology, properly understood, is or should be a moral discipline, and this is not to be understood in the rather narrow conception of ethical guidelines that so preoccupies practicing psychologists. Moral in a way in which there is a concern about what kind of people particular social arrangements create or produce. Moral in trying to comprehend what the implications are for subjectivity given the history of apartheid, the post-apartheid transition, and the hope for building a different and decent society? These are also deeply theoretical concerns and questions, so I am not advocating, or suggesting that Manganyi advocated or advocates, a narrow pragmatic or applied psychology in every instance.

Then there is the central role of biography in Chabani Manganyi's work. As Derek Hook says on the back cover of the memoir, this is Manganyi the storyteller. And what wonderful and intriguing stories, and stories of recovery, he has told about Es'kia Mphahlele, the novelist and literary theorist (Manganyi, 1983), the painter Gerard Sekoto who spent most of his adult years in exile in Paris (Manganyi, 1996; 2004a), and Dumile Feni, the artist and sculptor (1939-1991), another exile (Manganyi, 2012). We are in Manganyi's debt for having brought these artists into the light, otherwise they could so easily have remained invisible, and worse, forgotten. Reading the biographies, and the account of his biographical work, especially the interviews and contact with Gerard Sekoto, allows us to see him working as a biographer, as a methodologist, and as a psychologist in the best sense of that word.

Biography has been part of psychology for decades, but has occupied a rather marginal space both as methodology and as a substantive area of inquiry. This is slowly changing as at least in the realm of methodology, biographical methods, single case studies, 
and narrative approaches are accepted as legitimate parts of qualitative methods. And again, in his idiosyncratic way, Manganyi has produced some compelling psychological portraits in his biographical work. For those new to Manganyi's work, these biographies would be a good place to start.

Chabani Manganyi has not only been a scholar, a biographer, a psychologist, an intellectual, a writer, but has also contributed to the cause of higher education in South Africa having had appointments as a university vice chancellor, the director general of education under Minister Sibusiso Bhengu during Nelson Mandela's presidency, viceprincipal (2003-2006) of the University of Pretoria, and as the chairperson of the Council on Higher Education (CHE). And throughout the years of these demanding academic and educational jobs he has continued to write. This is not surprising, because that is what he is, first and foremost a writer. As Jenny Diski, the wonderful English writer and novelist, who died in 2016, said: "That is what I do, I write." To say that Manganyi is a writer might sound like I am saying something obvious, something banal even. Yet in the world of academia there are surprisingly few writers, and in my capacity as a journal editor it seems that the situation is getting worse. Academics publish, and yes to publish they must write, but many, too many, are not writers, and don't seem to care about the crafting of their work. There is a focus on the ends - the published article, or book - and the means, the writing, the crafting, the elegance (or at least an attempt at elegance) seem secondary if considered at all.

Reading Manganyi, from the early essays to his present memoir, one gets the impression of a man very serious about what he wants to say, and especially how he should go about saying it. One senses the pleasure, joy even, that Manganyi gets out of writing and thinking carefully about how he wants to formulate his ideas. Sadly, the likes of Chabani Manganyi are an increasingly rare breed, a man of letters, "a genuine and independent intellectual" to quote Tim Couzens (again from the back cover of the memoir), and a man who has devoted his life to ideas and the life of the mind in a socially engaged way. For this reason, it is unfortunate that so many of his ideas are unavailable to us as many of his books are out of print and quite difficult to get hold of, even through second-hand avenues.

It seems appropriate to conclude this short introduction to Manganyi's work and ideas by quoting the novelist Herman Hesse who in an essay (in 1930) titled "The magic of the book", found in his posthumously published text, My belief: Essays on life and art, wrote:

"Among the many worlds that man did not receive as a gift from nature but created out of his own mind, the world of books is the greatest... Without the word, without the writing of books, there is no history, there is no concept of humanity. And if 
anyone wants to try to enclose in a small space, in a single house or a single room, the history of the human spirit and to make it his own, he can only do this in the form of a collection of books." (from Brain Pickings Weekly, Maria Popova, 2016)

Over the years Chabani Manganyi has given us a wonderful collection of books, and now another one in his memoir, Apartheid and the making of a black psychologist. This memoir is a fascinating account of a black intellectual's struggle to assert his ideas, and through these make the world a better place, even in the most trying of circumstances - during the time of apartheid and beyond.

\section{References}

Hayes, G (2011) (Re-)introducing N Chabani Manganyi. PINS (Psychology in society), 41, 1-6.

Manganyi, N C (1973) Being-black-in-the-world. Johannesburg: Spro-cas / Ravan. Manganyi, N C (1977a) Alienation and the body in racist society: A study of the society that invented Soweto. New York: NOK Publishers.

Manganyi, N C (1977b) Mashangu's reverie and other essays.

Johannesburg: Ravan Press.

Manganyi, N C (1981) Looking through the keyhole: Dissenting essays on the Black experience. Johannesburg: Ravan Press.

Manganyi, N C (1983) Exiles and homecomings: A biography of Es'kia Mphahlele. Johannesburg: Ravan Press.

Manganyi, N C \& du Toit A (eds) (1990) Political violence and the struggle in South Africa. Johannesburg: Southern Book Publishers / London: Macmillan.

Manganyi, N C (1991) Treachery and innocence: Psychology and racial difference in South Africa. Johannesburg: Ravan Press.

Manganyi, N C (1996) A black man called Sekoto. Johannesburg: Witwatersrand University Press.

Manganyi, N C (2004a) Gerard Sekoto: “I am an African". Johannesburg: Witwatersrand University Press.

Manganyi, N C (ed) (2004b) On becoming a democracy: Transition and transformation in South African society. Pretoria: Unisa Press / Leiden: Koninklijke Brill NV. 
Manganyi, N C \& Attwell, D (eds) (2010) Bury me at the marketplace: Es'kia Mphahlele and company. Letters 1943-2006. Johannesburg: Wits University Press.

Manganyi, C (2012) The beauty of the line: Life and times of Dumile Feni. Sandton: KMM Review Publishing.

Manganyi, N C (2016) Apartheid and the making of a Black psychologist. Johannesburg: Wits University Press.

Ndebele. N S (2016) They are burning history. 10 ${ }^{\text {th }}$ Annual Helen Joseph Lecture, 14 September 2016, University of Johannesburg, Johannesburg.

Popova, M (2016) Hermann Hesse on the three types of readers and why the most transcendent form of reading is non-reading. Brain Pickings Weekly. Date retrieved 12 June 2016: https://www.brainpickings.org/?S=hermann+hesse+my+belief 